\title{
Technology in support of nature-based solutions requires understanding everyday experiences
}

\author{
Jiayang Li $^{1}$ and Joan Iverson Nassauer ${ }^{1}$
}

\begin{abstract}
Nature-based solutions that incorporate "smart" technologies to enhance ecosystem services delivery may change the way people experience urban nature in their everyday lives. We lay out a conceptual basis for considering such changes and their social impacts. Cities are increasingly recognized as complex social-ecological-technological systems in which sustainability and climate resilience require environmental function to be paired with innovative technology. Smart technologies for real-time monitoring and autonomous operation promise innovations in urban landscape management. However, this promise can be fully realized only with adequate consideration of social impacts. Drawing on literature in landscape studies, environmental psychology, behavioral economics, public health, and aesthetics, we initiate a discussion connecting everyday experiences of urban nature with the social impacts of smart nature-based solutions and with local communities' support for their implementation. We describe what makes pleasant everyday experiences of urban nature and their related well-being benefits and social and cultural values, and we elucidate how these experiences depend on perceivable landscape characteristics that are only sometimes directly linked to environmental functions. Then, based on this literature, we speculate about how adopting smart technologies to manage nature-based solutions may noticeably change the landscape in novel ways and have unintended negative impacts on everyday experiences of urban nature. We illustrate this with an example: smart stormwater management of retention ponds. We conclude that the risk of degraded everyday experiences of nature must be considered and addressed in the development of smart nature-based solutions. If pleasant everyday experiences are ensured through appropriate design, smart nature-based solutions may not only realize societal co-benefits, but also gain acceptance and continued support from the public for the whole set of ecosystem services they deliver.
\end{abstract}

Key Words: aesthetics; cultural ecosystem services; green infrastructure; landscape design; urban greenspace

\section{INTRODUCTION: TECHNOLOGY IN NATURE-BASED SOLUTIONS AND EXPERIENCES OF URBAN NATURE} Cities are increasingly understood as complex social-ecologicaltechnological systems, with both environmental function and technology driving transformations necessary for sustainability (Grimm et al. 2015, Tan et al. 2020, McPhearson et al. 2021). Technological advances, notably in computation, information and communication technology, Internet of Things, and robotics and autonomous systems, have prompted exploration of how urban systems might be transformed into "smart cities" (Albino et al. 2015, Martin et al. 2018). This includes adopting "smart" technologies to monitor and manage urban green infrastructure and nature-based solutions (NBS) to deliver ecosystem services in a more adaptive manner and help cities respond to climate change (Arts et al. 2015, Gulsrud et al. 2018, Nitoslawski et al. 2019, Goddard et al. 2021). For example, experiments have been conducted with real-time monitoring of soil moisture and automated irrigation to decrease mortality of urban trees under extreme drought and heat (Nitoslawski et al. 2019), and with holistic regulation of urban stormwater flows at the watershed scale to mitigate flooding risk and improve water quality (Bartos et al. 2018, Shishegar et al. 2021).

However, unlike adopting smart technologies to operate only built infrastructure, e.g., transportation or energy systems, incorporating smart technologies in urban ecosystems may cause noticeable landscape change, which may consequently change the way people experience urban nature. Such change is likely to be novel in appearance and ubiquitous in extent. Smart systems employ pervasive networks of computing devices to collect, process, and communicate data in real time. Although this can adapt relatively stable management regimes to be more responsive to climate change impacts, it may introduce unfamiliar dynamics into urban landscapes. For example, neighborhood parks and streets may have a novel appearance because they are employed to temporarily store stormwater (Lund et al. 2019). Even familiar landscape dynamics might change in frequency and magnitude: smart systems adopted in stormwater ponds can rapidly draw water levels up or down when controlling stormwater flow and storage (Mullapudi et al. 2017). To further enhance resulting regulating services, these landscape changes will often be systematic and ubiquitous, affecting both new and retrofitted urban infrastructure. This could change commonplace urban landscapes such as streets, neighborhoods, and greenspaces, affecting everyday experience of the urban landscape. Because of these likely novel and ubiquitous landscape effects, we raise the question of attendant qualitative changes in people's everyday experiences of urban nature. Will interventions informed by smart technologies bring urban residents pleasant nature experiences and greater well-being or degrade their experiences of urban nature?

In this paper, we hope to shed light on this question and offer conceptual insights about the social implications of incorporating smart technologies in nature-based solutions. A comprehensive understanding of how the uptake of smart technology might impact human-ecosystem interactions is not yet established (Goddard et al. 2021). To date, scattered discussions have identified both opportunities and unintended consequences including implications for stakeholder engagement, environmental justice, citizen empowerment, traditional biocultural and placebased knowledge, environmental education, environmental 
awareness, and nature contact, pointing to the urgent need for addressing long-term social considerations (Gulsrud et al. 2018, Martin et al. 2018, Galle et al. 2019, Nitoslawski et al. 2019, Goddard et al. 2021). We add to these propositions that how people experience urban nature in their everyday lives has fundamental social impacts, and we suggest that smart technologies might affect these experiences by noticeably changing urban landscapes in novel and unfamiliar ways.

To examine adoption of smart technologies in managing urban ecosystems, we focus specifically on "smart" nature-based solutions (sNBS), i.e., employing technological innovations broadly based on computation, information and communication technology, sensor networks, artificial intelligence, and robotics and autonomous systems to enhance certain ecosystem services. Others, in different topical contexts, have framed related terms and concepts such as digital conservation, green infrastructure automation, smart urban forests, or the "Internet of Nature" (Arts et al. 2015, Gulsrud et al. 2018, Galle et al. 2019, Nitoslawski et al. 2019). We focus on sNBS because NBS has been defined around a recognition of critical natural capital while also addressing societal challenges and providing co-benefits through innovative design and management of urban landscapes (European Commission 2015, Nesshöver et al. 2017, Pauleit et al. 2017, Dorst et al. 2019). Smart technologies are not inherently pro-environmental; if they are implemented to meet narrowly defined societal objectives, such technologies may actually undermine sustainability (Gulsrud et al. 2018, Goddard et al. 2021, McPhearson et al. 2021). For example, robotic lawn mowers may reduce human labor costs and encourage more extensive or frequent mowing in greenspaces, reinforcing norms for an intensively manicured landscape that may not support biodiversity. This paper focuses on scenarios where the adoption of smart technologies is explicitly intended to support sustainability and climate resilience.

In this paper, we use "urban nature" as an inclusive term to describe various outdoor biotic, e.g., plants, and abiotic, e.g., water, features that compose urban landscapes ranging from playing fields to nature reserves. Urban nature that city dwellers can regularly encounter in their everyday lives sometimes constitutes their only opportunity to interact with nature, and can be pivotal to well-being if associated with a feeling of pleasure (Andersson et al. 2014, Soga and Gaston 2016). The pandemic world makes this vividly apparent: many of us now know well the pleasure of walking down neighborhood streets while appreciating trees and home gardens, or even just getting some fresh air, and how much we yearn for such pleasure and the relief and relaxation it can offer (Corley et al. 2020, Kleinschroth and Kowarik 2020).

Strong evidence suggests that pleasant everyday experiences of urban nature can potentially enhance mental, physical, and social well-being (Markevych et al. 2017, Bratman et al. 2019), motivate pro-environmental decision and behavior (Alcock et al. 2020), and nurture a general connectedness to nature that may contribute to more sustainable lifestyles and culture (Lumber et al. 2017, Giusti et al. 2020). In this sense, pleasant everyday experiences of urban nature constitute cultural ecosystem services that potentially provide well-being benefits co-produced by people and the biophysical domain (Daniel et al. 2012, Andersson et al. 2015).
In contrast, landscapes that fail to provoke pleasant everyday experiences of urban nature may not support well-being, or may even result in "disservices" if the landscape is perceived as unsafe or unpleasant (Dronova 2019, Keeler et al. 2019).

In the following sections, we conceptualize everyday experiences of urban nature and describe how cultural and social values underlie pleasant everyday experiences that contribute to wellbeing. We elucidate that increased provision of ecosystem services does not necessarily ensure pleasant everyday experiences. Rather, human experiences must be examined and managed differently from environmental processes. Based on these ideas, we discuss how smart technologies may noticeably change the landscape in novel and unfamiliar ways that affect everyday experiences of urban nature. To identify potential social challenges for sNBS development, we highlight how implementation of smart technologies could create trade-offs between pleasant everyday experiences and environmental benefits, if sNBS are designed without adequate consideration of human experiences. Last, we illustrate the implications of implementation choices with an example: stormwater retention ponds managed by a smart system. We argue that, as pervasive adoption of smart systems in urban ecosystems accelerates, the potential effects of sNBS on everyday experiences of nature must be anticipated and addressed.

\section{PLEASANT EVERYDAY EXPERIENCES OF URBAN NATURE HAVE FAR-REACHING BENEFITS AND \\ VALUES}

Everyday experiences of urban nature are characterized by their regular and frequent occurrence, by the familiarity of the landscapes where they occur, and by their typical and ordinary experiential quality. What counts as everyday experiences of urban nature is context-dependent, but for many people, such experiences may take place in commonplace landscapes such as residential yards, streets, nearby parks, and the open spaces in between buildings. In contrast, more infrequent, unusual experiences of urban nature may be intentionally planned for and accessible only after travel, for example, in nature reserves, along shorelines, or in downtown parks and greenways that are distant from a neighborhood (Samuelsson et al. 2018).

We define "pleasant" experiences of urban nature as characterized by a feeling of pleasure in response to immediately noticeable characteristics of urban nature. Studies in aesthetics identify "immediately noticeable characteristics" as sensuous qualities and intrinsic properties of any object, phenomenon, and event, including landscapes (Eaton 1997, Gobster et al. 2007, Saito 2007). Pleasant experiences of urban nature involve all senses. For example, smell and sound contribute to landscape aesthetic experiences (Franco et al. 2017, Jeon and Jo 2020). In this paper, we focus on visual characteristics to initiate discussion about how sNBS may affect everyday experiences of urban nature.

The feeling of pleasure ultimately involves affective processes in which the feeling of pleasure arises directly and rapidly; at least it feels so to people who are experiencing it (Kaplan 1987). We recognize that pleasant experiences of the landscape involve complex underlying psychological processes that involve learning and cognition in varying ways and contexts. For example, many have described how environmental knowledge can and should affect pleasant landscape experiences (e.g., Carlson 2010). Yet we 
also note that there is little evidence to suggest that the general public attentively acquires environmental knowledge, especially about complex or unseen environmental processes, and further, employs this knowledge when casually interacting with urban nature in everyday life. People more easily learn from firsthand experiences of environmental phenomenon and the effects of learning are subject to the quality of their experiences (Kuang and Liao 2020).

Further, pleasant everyday experiences of urban nature are structured in large part by social norms and cultural traditions. These experiences can elicit positive feelings by providing familiarity, stability, comfort, safety, and reassurance that are necessary and appreciated in daily life (Saito 2017). Unlike aesthetic experiences associated with the wilderness or the scenic beauty of nature reserves, or the design of iconic public space projects, the feeling of pleasure arising from everyday experiences of urban nature may depend on more basic and commonly valued noticeable landscape qualities such as being orderly, under control, and well-kept (Nassauer 1995a, Saito 2007), or by a sense of place and attachment associated with a city or neighborhood (Dronova 2019, Gobster et al. 2007). This does not mean that pleasant everyday experiences of urban nature are not associated with scenic or well-designed places, or that aesthetic characteristics of urban nature are not surprising or fascinating. Many have suggested that ephemeral nature phenomena, notably seasonal and meteorological events, offer wonderful aesthetic surprises and discoveries in everyday experience, and that such experiences can benefit well-being (Beery et al. 2017). We note the "effortless attention" engaged by such phenomena, and the familiar and ordinary surroundings that allow such pleasures of fascination and surprise to emerge.

Moreover, whether noticeable characteristics of urban nature can elicit pleasant everyday experiences is contingent upon shared expectations of how a landscape should look in a specific context (Nassauer 1992, Gobster et al. 2007). The appearance of urban landscapes connotes social norms and cultural traditions, and is strongly shaped by vernacular practices that may be specific to a locale (Jackson 1984, Nassauer 1995b). A dense woodland may be perceived as pleasantly wild in a nature reserve but as forbiddingly wild in a neighborhood park. "Floodable" city parks and streets may be perceived as incompatible with public expectations that urban areas should stay dry and free from inundation (Liao 2012). Further, meeting such expectations for landscape appearance has moral implications (Nassauer 1995b, Saito 2007). For example, uniform and weed-free lawns in American home yards are often associated with good neighbors who take pride in their homes and communities (Nassauer 1995b, Larson and Brumand 2014). In this sense, everyday experiences of urban nature can reflect normative relationships within human communities, and between people and nature, bearing relational values that broadly contribute to a good, meaningful life (Chan et al. 2016).

Everyday experiences of urban nature arguably make important contributions to the mental, physical, and social health of city dwellers, presenting critical opportunities for urban ecosystems to deliver well-being benefits. Accumulating evidence has linked potential well-being benefits to more exposure to urban nature (Ekkel and de Vries 2017, Markevych et al. 2017, Bratman et al.
2019, Mossabir et al. 2021). For many people, indirect and incidental experiences of urban nature in everyday life - for example, views from homes, offices, and classrooms, or nature encounters during commuting - constitute the majority of regular nature experiences, occurring much more often than intentional visits to gardens and public parks (Cox et al. 2017). Pleasant experiences of urban nature may help reduce stress and restore attention fatigue (Markevych et al. 2017, Bratman et al. 2019). Further, the quality of everyday experiences may moderate well-being benefits, affecting the frequency of peoples' interactions with nature. For example, Beery et al. (2017) discussed how design choices in greenspaces, such as an appealing plant palette with species of different textures and seasonal color changes, may evoke pleasant experiences of urban nature, thereby "nudging" people to use greenspaces more often and receive greater well-being support.

\section{INCREASED PROVISION OF ECOSYSTEM SERVICES DOES NOT ENSURE PLEASANT EVERYDAY EXPERIENCES}

In everyday life, what people enjoy in or expect from a landscape may or may not align with its environmental benefits (Nassauer 1992). On the fundamental level of human perception, environmental phenomena may occur at spatial scales where humans cannot directly perceive or notice them, whereas people experience urban nature through the immediately noticeable landscape characteristics of vegetation, water, topography, and built structures in the "perceptible realm" (Gobster et al. 2007). Pleasant experiences are related to environmental processes by landscape perception, which is shaped by social and cultural phenomena and arises from psychological processes rather than from scientific assessments of ecosystem services (Gobster et al. 2007, Andersson et al. 2014). Consequently, comparing ecosystem services with aesthetic experiences, "what is good may not look good" (Nassauer 1995b:161).

Moreover, everyday experiences of urban nature are closely related to pragmatic considerations such as property management that can powerfully motivate people's attitudes and behaviors toward the landscape (Saito 2017). For example, vegetation maintenance norms for neighborhoods (Cook et al. 2012) and urban nature in views from a home (Sander and Haight 2012) can be decisive factors for property value. Pro-environmental interventions in familiar landscapes, such as street trees, neighborhood stormwater controls and greenspaces, workplace green roofs, or home yards, are likely to be subject to normative community expectations for landscape appearance, as we discussed in the previous section. Consequently, people living in a neighborhood dominated by manicured lawns may apply lawn chemicals regardless of what they know about impacts on water quality. And residents may object to adding shrubs and grasses to neighborhood stormwater ponds, despite knowing related water quality benefits, because they worry that taller plants could block views to water and degrade aesthetic experiences (Monaghan et al. 2016).

The distinction between pleasant everyday experiences and environmental benefits has been noted in recent studies that address potential trade-offs between cultural and other ecosystem services and challenges for ensuring multiple benefits and values of urban nature (Dronova 2019, Keeler et al. 2019). It also has 
Table 1. Examples of ways smart technologies might be employed in nature-based solutions (NBS) and their potential effects on everyday experience. Note that these examples are speculative; we do not intend to review existing practices or predict future trends here.

\begin{tabular}{|c|c|c|c|}
\hline & \multicolumn{3}{|c|}{ NBS and related smart technologies } \\
\hline & $\begin{array}{l}\text { Street trees/green roofs } \\
\text { Automated irrigation based on } \\
\text { monitoring and forecasting data for } \\
\text { soil moisture and weather }\end{array}$ & \begin{tabular}{l}
\multicolumn{1}{c}{ Stormwater controls } \\
Real-time monitoring and control of \\
stormwater flow among retention/ \\
detention sites, including temporary \\
storage in built areas
\end{tabular} & $\begin{array}{l}\text { Urban greenspaces } \\
\text { Restoration, conservation, or creation of } \\
\text { high-quality habitats with minimal } \\
\text { human influence }\end{array}$ \\
\hline \multicolumn{4}{|c|}{ Intended and unintended impacts } \\
\hline $\begin{array}{l}\text { Ecosystem services delivery } \\
\text { objective }\end{array}$ & $\begin{array}{l}\text { Provisioning of water resources in } \\
\text { arid cities }\end{array}$ & $\begin{array}{l}\text { More effectively improve water quality } \\
\text { and mitigate flood risk }\end{array}$ & $\begin{array}{l}\text { Biodiversity support and supporting } \\
\text { services }\end{array}$ \\
\hline $\begin{array}{l}\text { Noticeable change in the } \\
\text { landscape }\end{array}$ & $\begin{array}{l}\text { Yellow and brown or withering } \\
\text { plants during hot and drought } \\
\text { seasons }\end{array}$ & $\begin{array}{l}\text { Temporarily flooded streets, lawns, or } \\
\text { parking area; drained ponds with little } \\
\text { water and revealed sediments }\end{array}$ & $\begin{array}{l}\text { Unmaintained, spontaneous plants that } \\
\text { look wild or "weedy"; presence of } \\
\text { wildlife that elicits little affection, but } \\
\text { unpleasantness or even danger (e.g., } \\
\text { insects, snakes) }\end{array}$ \\
\hline $\begin{array}{l}\text { Potential degradation in } \\
\text { everyday experiences }\end{array}$ & $\begin{array}{l}\text { Undermined "green" image and } \\
\text { aesthetic value; perceived unhealthy } \\
\text { or/and lack of care }\end{array}$ & $\begin{array}{l}\text { Perceived flooding risk and safety hazard; } \\
\text { messiness and unpleasant odor; } \\
\text { undermined aesthetic value }\end{array}$ & $\begin{array}{l}\text { Lack of legibility or culturally and } \\
\text { socially familiar cues; decreased } \\
\text { perceived safety; loss of opportunities } \\
\text { for stewardship and taking care of } \\
\text { "nature" }\end{array}$ \\
\hline
\end{tabular}

implications for equity and environmental justice (Anguelovski et al. 2019, Dronova 2019). Landscape interventions that appear to degrade everyday experiences may be unwanted in many communities and sited in disempowered ones (Wilson 2009). Even interventions that are developed to benefit communities where residents suffer from disproportionately distributed environmental stressors may not fully support health equity if they do not ensure pleasant everyday experiences (Woolf 2017). For example, residents may object to planting of trees near their home because they perceive trees as a maintenance burden or a threat to personal safety, even though urban trees can moderate human experience of extreme heat (Carmichael and McDonough 2018, Nassauer et al. 2021).

Improving the attractiveness of urban environments and enhancing human well-being are among the principal goals for developing NBS in cities (European Commission 2015, Raymond at el. 2017). These benefits should not be assumed when NBS are implemented, however. Rather, various impacts of NBS, both positive and negative, must be anticipated and investigated from coupled social, ecological, and technological perspectives (Kabisch et al. 2016, Nesshöver et al. 2017, Keeler et al. 2019). This is particularly relevant for urban sNBS that employ smart technologies to pervasively intervene in environmental processes and functions in a novel manner. Unless sNBS are developed with attention to noticeable landscape characteristics, they may fail to offer pleasant everyday experiences and related well-being benefits. In contrast, if urban landscapes affected by sNBS are perceived as pleasant, they are more likely to be culturally sustainable: accepted and embraced over time (Nassauer 1997, Dronova 2019).

\section{SMART NBS MAY PERVASIVELY AND NOTICEABLY CHANGE URBAN LANDSCAPES IN NOVEL WAYS}

Smart technologies may help cities more efficiently and effectively manage NBS to provide ecosystem services such as stormwater management and microclimate regulation in response to climate change (Gulsrud et al. 2018, Nitoslawski et al. 2019, Goddard et al. 2021). The very effectiveness of these technologies in enhancing the regulation ecosystem services of both new and retrofitted urban systems could lead to their rapid and ubiquitous adoption (Goddard et al. 2021). This could pervasively and noticeably change urban landscapes in ways that are novel and unfamiliar to residents, unintentionally affecting their everyday experiences of urban nature (Table 1) and creating public resistance to sNBS, even if smart systems enhance ecosystem services.

Smart technologies that allow real-time monitoring and control can transform NBS from passively relying on embodied environmental processes to actively interacting and intervening with these processes to deliver more ecosystem services. This may help NBS to better respond and adapt to constantly changing and increasingly unpredictable environmental stressors. However, at the same time, it may introduce noticeable and unfamiliar changes in landscapes dynamics. Although people often enjoy the beauty of ephemeral and regularly changing nature phenomena such as seasonal transitions, sunsets, and rainbows, "surprises" resulting from real-time control like flooded streets or drained ponds are not familiar landscape changes. Such novel dynamics in noticeable landscape characteristics may seem unrecognizable and incomprehensible, and challenge expectations and preferences for a relatively static look of the landscape in daily life (Mozingo 1997).

Moreover, smart technologies may drive innovations in NBS design and management decision making, especially regarding maintenance. Smart systems enable previously unavailable forms of data collection and modeling, which promote autonomous systems that require less human agency. For example, rather than being determined by maintenance staffs' experience and knowledge, irrigation of urban street trees and plants can be 
automated based on real-time monitoring as well as forecasting of soil moisture and weather events. Such an approach may promise more efficient water use and lower plant mortality, while potentially altering the noticeable characteristics of plants (e.g., leaf color, species evenness). There are even discussions about completely removing human perception and control from ecological restoration, using robotics and autonomous systems instead to rewild landscapes and support biodiversity (Cantrell et al. 2017, Goddard et al. 2021).

Current scholarship about sNBS development may assume that people welcome accompanying landscape change because such change may make environmental processes and dynamics more apparent in urban landscapes. Or, that sufficient community engagement or new knowledge will easily nurture a positive attitude toward novel changes happening in their everyday landscape surroundings (Lund et al. 2019). However, strong community objections against pro-environmental landscape interventions, including constructed wetlands, wind turbines, and solar farms, have occurred in the past, and such objections have not been easily resolved by educating the community about their environmental benefits (Sánchez-Pantoja et al. 2018, Vlami et al. 2020). Such interventions introducing noticeable unfamiliar processes or novel structures into the landscape were met with skepticism, disapproval, or fear by residents.

As we have described above, local residents may share expectations for everyday experiences of urban nature that derive from vernacular practices, social norms, and cultural traditions. Along with formal regulations and institutional characteristics of municipal government such as disciplinary silos (Nitoslawski et al. 2019), these expectations constitute the broader institutional context that prevents or encourages cities from incorporating smart technologies in NBS (Kiparsky et al. 2013). We suggest that, where local communities are concerned about the unfamiliar appearance of landscapes affected by sNBS, institutional drag on adoption may be amplified, even to the point of preventing adoption of environmentally beneficial technologies.

Invisible or remote environmental functions or ecosystem services are unlikely to compensate for potential degradation of pleasant experiences, a key cultural ecosystem service, in sNBS. The human tendency for status quo bias and loss aversion implies a strong resistance to exchanging palpable loss of pleasant experiences for an intangible gain in environmental benefits (Samuelson and Zeckhauser 1988, Tversky and Kahneman 1991, Schill et al. 2019). Sustainability and resilience challenges that sNBS address can seem so distant and unrelated to everyday life that people may lack motivation to change their attitude and behavior unless they have impactful personal experiences, for instance, experience with extreme events like wildfires and flooding (Kunreuther et al. 2014). "Humans are not optimization algorithms" (Schill et al. 2019:1076). Rather, people act within socio-cultural contexts, and under uncertainty tend not to favor decisions with long-term benefits. As a result, people may not favor sNBS that promote environmental functions and related ecosystem services if sNBS rob a landscape of socially and culturally familiar characteristics (Nassauer 1995b) or make it appear confusingly illegible or even unsafe (Kaplan 1987, Monzingo 1997). Rather, sNBS that degrade everyday experiences of urban nature may be rejected or ultimately altered amid community backlash.
Urban landscapes affected by sNBS embody environmental processes and ecological functions. At the same time, they are also visible entities that different people, who may or may not have environmental knowledge, notice and respond to (Nassauer 1992, Termorshuizen and Opdam 2009). Because sNBS are intended to provide ecosystem services and societal co-benefits, and because the appearance of sNBS will affect people's everyday experiences of urban nature and, consequently, their support for sNBS, understanding everyday experiences of sNBS is necessary to the sustainable and equitable delivery of ecosystem services by sNBS.

\section{AN ILLUSTRATIVE CASE: SMART STORMWATER PONDS IN SOCIAL-ECOLOGICAL-TECHNOLOGICAL SYSTEMS}

We illustrate ideas discussed in previous sections by examining urban stormwater controls, a common focus in NBS (Keeler et al. 2019) that incorporates smart technologies in stormwater management. Advances in sensing, computation, and wireless communication technologies have inspired development of smart stormwater ponds that are monitored in real time and controlled across a watershed as a whole system (Bartos et al. 2018, Lund et al. 2019). Such a sNBS presents opportunities to regulate urban stormwater to more effectively and strategically address extreme precipitation events under climate change. Specifically, individual ponds at different locations can be remotely operated to drain water before storms to free up storage capacity and to retain water longer to reduce peak flows into stormwater infrastructure after storms (Bartos et al. 2018, Shishegar et al. 2021). However, these operations can introduce noticeable unfamiliar landscape change into residential neighborhoods, parks, or commercial plazas that contain ponds. For example, draining ponds before a storm may reveal accumulated sediment, and retaining more water for a longer time after storms may raise water levels, resembling flood conditions. These changes have implications for everyday experiences of urban nature.

Stormwater retention ponds characterized by perennial open water are widely recognized as an amenity that offers pleasant everyday experiences to nearby residents (Bastien et al. 2012, Lähde et al. 2019). Surface water with good clarity is a highly preferred landscape feature and is often perceived as natural, beautiful, and relaxing (Herzog 1985, White et al. 2010) with potential for enhancing well-being (Völker and Kistemann 2011, McDougall et al. 2020). Moreover, compared with other stormwater controls that do not have perennial open water, retention ponds may be associated with higher home prices nearby (Sohn et al. 2020). However, fluctuations of water level and surface extent caused by smart technologies could raise community concerns about safety, aesthetics, and public health. High water concerns may be related to localized flooding, drowning hazards, or physical contact with polluted water (Jarvie et al. 2017, Williams et al. 2019). Low water concerns may be about revealed sediments looking dirty and unattractive (Herzog 1985, Cottet et al. 2013).

Drawing on work from our ongoing investigation of smart stormwater management in three American cities (Ann Arbor, Michigan; South Bend, Indiana; and Knoxville, Tennessee), we illustrate how smart technologies might affect everyday experiences associated with stormwater ponds. We developed digital visualizations of ponds for which water levels could be 
manipulated by smart stormwater management systems to adapt to extreme storm events, as shown in Figure 1. Then, we employed these visualizations in mail surveys of residents of each city. Respondents $(n=977)$ rated pond landscapes on a 5-point Likert scale on three dimensions of everyday experiences: attractiveness, neatness, and safety. Below, for the purposes of illustrating the implications of our argument for consideration of everyday experiences of sNBS, we report from our survey data.

Fig. 1. An example of smart nature-based solutions (sNBS): a retention pond in a residential area that is managed by a smart stormwater system. The pond was depicted with different water levels: (1) typical, (2) low, as if the pond were drained 24 hours before a storm to free up storage capacity, and (3) high, as if water were retained at a higher than typical level for as long as 48 hours after a storm (visualizations by Yiran Shen and Yuanqiu Feng).

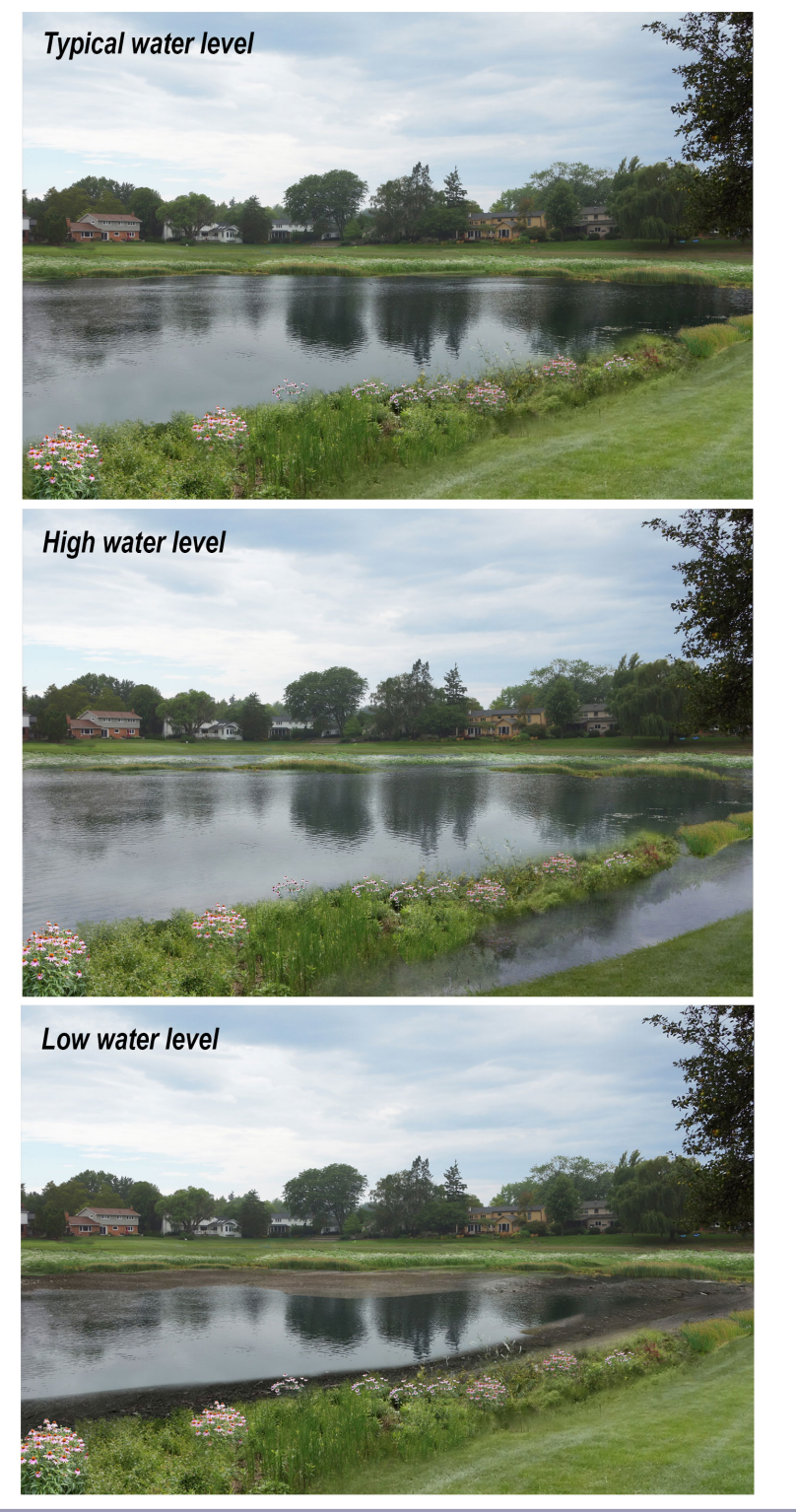

Our data suggest that different pond water levels, manipulated by smart technology, were associated with different everyday experiences. For the pond shown in Figure 1, although ratings for attractiveness, neatness, and safety of both high and low water levels were lower than for the typical water level, the high water level tended to be rated as least safe, and the lower water condition tended to be rated as least attractive. Survey visualizations also included ponds located in parks and commercial areas, and with other shoreline configurations and plants. For another pond, which was depicted in a park and with wetland plants along the shore, everyday experiences associated with the high water level were similar to those associated with the typical water level, whereas the low water level was perceived as far less attractive and safe than the typical water level.

These experiences of high and low water levels, compared to the typical water level, are particularly relevant for considering how everyday experiences of a pond may relate to its stormwater regulation services. Both pre-storm draining and after-storm extra retention regulate flows, contributing to downstream water quality and flood prevention. Yet the appearance of the pond associated with each of these operations elicited different experiences. Knowing about residents' likely perceptions, local managers might opt to design or locate ponds differently. For instance, having a steeper basin that can contain increased volumes of water within a smaller surface extent, or draining ponds only within a few hours of an expected storm might reduce degradation of everyday landscape experience. Further, other design variables, like shoreline vegetation and land use context, might be used to further reduce degradation or even enhance everyday experiences of stormwater pond landscapes.

This example illustrates how provision of some ecosystem services by sNBS raises questions about the provision of what we assert is an essential cultural ecosystem service, pleasant everyday experiences of urban nature. At the "human scale," pleasant everyday experiences require attention to the noticeable characteristics of urban nature. These everyday experiences cannot be directly inferred from analyzing environmental functions that may depend on unperceivable environmental processes. Rather, sNBS must be intentionally designed to ensure pleasant everyday experiences. By gaining a better understanding of how people will perceive and experience urban landscapes affected by smart technologies, adoption of sNBS may avoid or at least minimize lost cultural ecosystem services while it also eases the pathway for more widespread adoption.

\section{CONCLUSION}

Cities may increasingly employ smart technologies to facilitate how nature-based solutions are conceived and managed to address sustainability and climate resilience. However, how smart technologies may affect people's everyday experiences of urban nature also deserves attention. In this paper, we elucidate how smart NBS may degrade everyday experiences of urban nature when they introduce noticeable landscape change, particularly unfamiliar landscape dynamics. Loss of pleasant experiences of urban nature could undermine the well-being of residents and have negative impacts on community identity, property management, and health equity. Further, objections from residents who perceive unfamiliar changes as degrading their everyday experiences of local landscapes, coupled with managers' 
responses to these objections, may hinder the systematic adoption and long-term success of sNBS for delivering overall ecosystem services.

Pleasant everyday experiences of urban nature subtly connote basic human needs, deep-rooted cultural values, and powerful social norms. These connotations of landscape appearance can change: the history of landscape aesthetics suggests that both individuals and societies sometimes learn to attach these connotations to different landscape characteristics over time. Yet we caution that attempts to force change in deep-seated perceptual responses to everyday surroundings may have disappointing or damaging results. Although it is possible that more knowledge of environmental functions underlying unfamiliar landscape changes may lead to greater acceptance, we assert that people are more likely to appreciate unfamiliar landscape characteristics through lived experiences that they find pleasant and valuable. Pleasant everyday experiences should be evident for sNBS to gain societal legitimacy (Harris-Lovett et al. 2015) or for evolution to a new aesthetic norm for highly functioning urban nature (Nassauer 1992, Meyer 2008). By directly connecting people to environmental phenomena in their daily life, pleasant everyday experiences of urban nature may serve as a nudge to help accelerate the societal transformation urgently needed to respond to environmental crises, guiding people to accept and support sNBS that they might otherwise reject (Nassauer 2011, Beery et al. 2017).

For sNBS to provide both pleasant everyday experiences and other ecosystem services, consideration of the relationship between their noticeable characteristics and local residents' landscape perceptions must be integral to their development. This demands simultaneous attention to both the noticeable characteristics of sNBS that are inherent to their environmental functions and to noticeable characteristics that make for pleasant everyday experiences. Recognizing pleasant everyday experiences of urban nature as cultural ecosystem services that occur at the human scale should suggest that design, evaluation, and assessment of sNBS must include these dimensions (Raymond et al. 2017). Further, contradictions between these dimensions may sometimes be amenable to resolution by design and planning. Specifically, co-design and co-creation processes that engage researchers and design professionals with local residents may help to integrate expert knowledge and local perspectives (Kabisch et al. 2016, Frantzeskaki 2019).

Will the adoption of smart technologies in NBS offer pleasant everyday experiences of urban nature and open new pathways to enhance the well-being of urban residents? We conclude that sNBS may noticeably change commonplace urban landscapes in novel and unfamiliar ways, leading to unintended loss of pleasant everyday experiences. Attention to such potential impacts of noticeable landscape characteristics - anticipating community resistance and avoiding harm - may be essential to the success of smart sustainability efforts. Furthermore, because everyday experiences of urban nature can powerfully motivate attitudes and behavior, sNBS that are designed to ensure pleasant experiences could elevate public appreciation for landscape change that supports ecosystem services. Effective sNBS intervention will require holistic understanding of socialecological-technological interactions. Along with investigation of the technological, ecological, and governance dimensions of sNBS, it is critical to address how sNBS may affect everyday experiences of urban nature. These experiences have far-reaching implications for well-being and behavior, and can fundamentally affect societal response to innovation. Managing urban landscapes to be cherished and celebrated in everyday life is not trivial or extraneous to building sustainable and resilient cities. Rather, it suggests a pathway to such a future.

Responses to this article can be read online at: https://www.ecologyandsociety.org/issues/responses. $\mathrm{php} / 12838$

\section{Acknowledgments:}

We gratefully acknowledge support from the U.S. National Science Foundation for this work: SCC-IRF 1737432, Overcoming Social and Technical Barriers for the Broad Adoption of Smart Stormwater Systems.

\section{Data Availability:}

Datalcode sharing is not applicable to this article because no datal code were analyzed in this study.

\section{LITERATURE CITED}

Albino, V., U. Berardi, and R. M. Dangelico. 2015. Smart cities: definitions, dimensions, performance, and initiatives. Journal of Urban Technology 22(1):3-21. https://doi.org/10.1080/10630732.2014 .942092

Alcock, I., M. P. White, S. Pahl, R. Duarte-Davidson, and L. E. Fleming. 2020. Associations between pro-environmental behaviour and neighbourhood nature, nature visit frequency and nature appreciation: evidence from a nationally representative survey in England. Environment International 136:105441. https://doi.org/10.1016/j.envint.2019.105441

Andersson, E., S. Barthel, S. Borgström, J. Colding, T. Elmqvist, C. Folke, and Å. Gren. 2014. Reconnecting cities to the biosphere: stewardship of green infrastructure and urban ecosystem services. Ambio 43(4):445-453. https://doi.org/10.1007/s13280-014-0506$\mathrm{y}$

Andersson, E., M. Tengö, T. McPhearson, and P. Kremer. 2015. Cultural ecosystem services as a gateway for improving urban sustainability. Ecosystem Services 12:165-168. https://doi. org/10.1016/j.ecoser.2014.08.002

Anguelovski, I., J. J. T. Connolly, M. Garcia-Lamarca, H. Cole, and H. Pearsall. 2019. New scholarly pathways on green gentrification: what does the urban 'green turn' mean and where is it going? Progress in Human Geography 43(6):1064-1086. https://doi.org/10.1177/0309132518803799

Arts, K., R. van der Wal, and W. M. Adams. 2015. Digital technology and the conservation of nature. Ambio 44(4):661-673. https://doi.org/10.1007/s13280-015-0705-1 
Bartos, M., B. Wong, and B. Kerkez. 2018. Open storm: a complete framework for sensing and control of urban watersheds. Environmental Science: Water Research and Technology 4 (3):346-358. https://doi.org/10.1039/C7EW00374A

Bastien, N., S. Arthur, and M. McLoughlin. 2012. Valuing amenity: public perceptions of sustainable drainage systems ponds. Water and Environment Journal 26(1):19-29. https://doi. org/10.1111/j.1747-6593.2011.00259.x

Beery, T. H., C. M. Raymond, M. Kytta, A. S. Olafsson, T. Plieninger, M. Sandberg, M. Stenseke, M. Tengo, and K. I. Jonsson. 2017. Fostering incidental experiences of nature through green infrastructure planning. Ambio 46(7):717-730. https://doi. org/10.1007/s13280-017-0920-Z

Bratman, G. N., C. B. Anderson, M. G. Berman, B. Cochran, S. De Vries, J. Flanders, C. Folke, H. Frumkin, J. J. Gross, T. Hartig, P. H. Kahn, M. Kuo, J. J. Lawler, P. S. Levin, T. Lindahl, A. MeyerLindenberg, R. Mitchell, Z. Ouyang, J. Roe, L. Scarlett, J. R. Smith, M. Van den Bosch, B. W. Wheeler, M. P. White, H. Zheng, and G. C. Daily. 2019. Nature and mental health: an ecosystem service perspective. Science Advances 5(7):eaax0903. https://doi. org/10.1126/sciadv.aax0903

Cantrell, B., L. J. Martin, and E. C. Ellis. 2017. Designing autonomy: opportunities for new wildness in the Anthropocene. Trends in Ecology \& Evolution 32(3):156-166. https://doi. org/10.1016/j.tree.2016.12.004

Carlson, A. 2010. Contemporary environmental aesthetics and the requirements of environmentalism. Environmental Values 19 (3):289-314. https://doi.org/10.3197/096327110X519844

Carmichael, C. E., and M. H. McDonough. 2018. The trouble with trees? Social and political dynamics of street tree-planting efforts in Detroit, Michigan, USA. Urban Forestry \& Urban Greening 31:221-229. https://doi.org/10.1016/j.ufug.2018.03.009

Chan, K. M., P. Balvanera, K. Benessaiah, M. Chapman, S. Díaz, E. Gómez-Baggethun, R. Gould, N. Hannahs, K. Jax, S. Klain, and G. W. Luck. 2016. Opinion: why protect nature? Rethinking values and the environment. Proceedings of the National Academy of Sciences 113(6):1462-1465. https://doi.org/10.1073/ pnas. 1525002113

Cook, E. M., S. J. Hall, and K. L. Larson. 2012. Residential landscapes as social-ecological systems: a synthesis of multiscalar interactions between people and their home environment. Urban Ecosystems 15(1):19-52. https://doi.org/10.1007/s11252-011-0197-0

Corley, J., J. A. Okely, A. M. Taylor, D. Page, M. Welstead, B. Skarabela, P. Redmond, S. R. Cox, and T. C. Russ. 2020. Home garden use during COVID-19: associations with physical and mental wellbeing in older adults. Journal of Environmental Psychology 73:101545. https://doi.org/10.1016/j.jenvp.2020.101545

Cottet, M., H. Piégay, and G. Bornette. 2013. Does human perception of wetland aesthetics and healthiness relate to ecological functioning? Journal of Environmental Management 128:1012-1022. https://doi.org/10.1016/j.jenvman.2013.06.056

Cox, D. T. C., H. L. Hudson, D. F. Shanahan, R. A. Fuller, and K. J. Gaston. 2017. The rarity of direct experiences of nature in an urban population. Landscape and Urban Planning 160:79-84. https://doi.org/10.1016/j.landurbplan.2016.12.006

Daniel, T. C., A. Muhar, A. Arnberger, O. Aznar, J. W. Boyd, K. M. A. Chan, R. Costanza, T. Elmqvist, C. G. Flint, P. H. Gobster, A. Grêt-Regamey, R. Lave, S. Muhar, M. Penker, R. G. Ribe, T. Schauppenlehner, T. Sikor, I. Soloviy, M. Spierenburg, K. Taczanowska, J. Tam, and A. von der Dunk. 2012. Contributions of cultural services to the ecosystem services agenda. Proceedings of the National Academy of Sciences 109(23):8812-8819. https:// doi.org/10.1073/pnas.1114773109

Dorst, H., A. van der Jagt, R. Raven, and H. Runhaar. 2019. Urban greening through nature-based solutions: key characteristics of an emerging concept. Sustainable Cities and Society 49:101620. https://doi.org/10.1016/j.scs.2019.101620

Dronova, I. 2019. Landscape beauty: a wicked problem in sustainable ecosystem management? Science of the Total Environment 688:584-591. https://doi.org/10.1016/j.scitotenv.2019.06.248

Eaton, M. M. 1997. The beauty that requires health. Pages 85-106 in J. I. Nassauer, editor. Placing nature: culture and landscape ecology. Island, Washington, D.C., USA.

Ekkel, E. D., and S. de Vries. 2017. Nearby green space and human health: evaluating accessibility metrics. Landscape and Urban Planning 157:214-220. https://doi.org/10.1016/j.landurbplan.2016.06.008

European Commission. 2015. Towards an EU research and innovation policy agenda for nature-based solutions and renaturing cities. Final report of the horizon 2020 expert group on nature-based solutions and re-naturing cities. DirectorateGeneral for Research and Innovation (European Commission), Brussels, Belgium. [online] URL: https://op.europa.eu/en/ publication-detail/-/publication/fb117980-d5aa-46df-8edc-af367cddc202

Franco, L. S., D. F. Shanahan, and R. A. Fuller. 2017. A review of the benefits of nature experiences: more than meets the eye. International Journal of Environmental Research and Public Health 14(8):864. https://doi.org/10.3390/ijerph14080864

Frantzeskaki, N. 2019. Seven lessons for planning nature-based solutions in cities. Environmental Science \& Policy 93:101-111. https://doi.org/10.1016/j.envsci.2018.12.033

Galle, N. J., S. A. Nitoslawski, and F. Pilla. 2019. The internet of nature: how taking nature online can shape urban ecosystems. Anthropocene Review 6(3):279-287. https://doi.org/10.1177/205$\underline{3019619877103}$

Giusti, M., W. Wang, and T. Marriott. 2020. Connecting land: a transdisciplinary workshop to envision a nature-connecting human habitat. Cities \& Health. https://doi.org/10.1080/23748834.2020.1742491

Gobster, P. H., J. I. Nassauer, T. C. Daniel, and G. Fry. 2007. The shared landscape: what does aesthetics have to do with ecology? Landscape Ecology 22(7):959-972. https://doi.org/10.1007/ $\underline{\text { s10980-007-9110-X }}$

Goddard, M. A., Z. G. Davies, S. Guenat, M. J. Ferguson, J. C. Fisher, A. Akanni, T. Ahjokoski, P. M. Anderson, F. Angeoletto, C. Antoniou, A. J. Bates, A. Barkwith, A. Berland, C. J. Bouch, 
C. C. Rega-Brodsky, L. B. Byrne, D. Cameron, R. Canavan, T. Chapman, S. Connop, S. Crossland, M. C. Dade, D. A. Dawson, C. Dobbs, C. T. Downs, E. C. Ellis, F. J. Escobedo, P. Gobster, N. M. Gulsrud, B. Guneralp, A. K. Hahs, J. D. Hale, C. Hassall, M. Hedblom, D. F. Hochuli, T. Inkinen, I.-C. Ioja, D. Kendal, T. Knowland, I. Kowarik, S. J. Langdale, S. B. Lerman, I. MacGregor-Fors, P. Manning, P. Massini, S. McLean, D. D. Mkwambisi, A. Ossola, G. Pérez Luque, L. Pérez-Urrestarazu, K. Perini, G. Perry, T. J. Pett, K. E. Plummer, R. A. Radji, U. Roll, S. G. Potts, H. Rumble, J. P. Sadler, S. de Saille, S. Sautter, C. E. Scott, A. Shwartz, T. Smith, R. P. H. Snep, C. D. Soulsbury, M. C. Stanley, T. Van de Voorde, S. J. Venn, P. H. Warren, C.-L. Washbourne, M. Whitling, N. S. G. Williams, J. Yang, K. Yeshitela, K. P. Yocom, and M. Dallimer. 2021. A global horizon scan of the future impacts of robotics and autonomous systems on urban ecosystems. Nature Ecology \& Evolution 5(2):219-230. https://doi.org/10.1038/s41559-020-01358-Z

Grimm, N. B., E. M. Cook, R. L. Hale, and D. M. Iwaniec. 2015. Benefits and challenges of built, natural or hybrid system function. Pages 203-212 in K. Seto, W. Solecki, and C. Griffith, editors. The Routledge handbook of urbanization and global environmental change. Routledge, London, UK.

Gulsrud, N. M., C. M. Raymond, R. L. Rutt, A. S. Olafsson, T. Plieninger, M. Sandberg, T. H. Beery, K. I. Jönsson. 2018. 'Rage against the machine'? The opportunities and risks concerning the automation of urban green infrastructure. Landscape and Urban Planning 180:85-92. https://doi.org/10.1016/j.landurbplan.2018.08.012

Harris-Lovett, S. R., C. Binz, D. L. Sedlak, M. Kiparsky, and B. Truffer. 2015. Beyond user acceptance: a legitimacy framework for potable water reuse in California. Environmental Science and Technology 49(13):7552-7561. https://doi.org/10.1021/acs.est.5b00504

Herzog, T. R. 1985. A cognitive analysis of preference for waterscapes. Journal of Environmental Psychology 5(3):225-241. https://doi.org/10.1016/S0272-4944(85)80024-4

Jackson, J. B. 1984. Discovering the vernacular landscape. Yale University Press, New Haven, Connecticut, USA.

Jarvie, J., S. Arthur, and L. Beevers. 2017. Valuing multiple benefits, and the public perception of SUDS ponds. Water 9 (2):128. https://doi.org/10.3390/w9020128

Jeon, J. Y., and H. I. Jo. 2020. Effects of audio-visual interactions on soundscape and landscape perception and their influence on satisfaction with the urban environment. Building and Environment 169:106544. https://doi.org/10.1016/j.buildenv.2019.106544

Kabisch, N., N. Frantzeskaki, S. Pauleit, S. Naumann, M. Davis, M. Artmann, D. Haase, S. Knapp, H. Korn, J. Stadler, K. Zaunberger, and A. Bonn. 2016. Nature-based solutions to climate change mitigation and adaptation in urban areas: perspectives on indicators, knowledge gaps, barriers, and opportunities for action. Ecology and Society 21(2):39. https:// doi.org/10.5751/ES-08373-210239

Kaplan, S. 1987. Aesthetics, affect, and cognition: environmental preference from an evolutionary perspective. Environment and Behavior 19(1):3-32. https://doi.org/10.1177/0013916587191001
Keeler, B. L., P. Hamel, T. McPhearson, M. H. Hamann, M. L. Donahue, K. A. M. Prado, K. K. Arkema, G. N. Bratman, K. A. Brauman, J. C. Finlay, A. D. Guerry, S. E. Hobbie, J. A. Johnson, G. K. MacDonald, R. I. McDonald, N. Neverisky, and S. A. Wood. 2019. Social-ecological and technological factors moderate the value of urban nature. Nature Sustainability 2 (1):29-38. https://doi.org/10.1038/s41893-018-0202-1

Kiparsky, M., D. L. Sedlak, B. H. Thompson, and B. Truffer. 2013. The innovation deficit in urban water: the need for an integrated perspective on institutions, organizations, and technology. Environmental Engineering Science 30(8):395-408. https://doi.org/10.1089/ees.2012.0427

Kleinschroth, F., and I. Kowarik. 2020. COVID-19 crisis demonstrates the urgent need for urban greenspaces. Frontiers in Ecology and the Environment 18(6):318. https://doi.org/10.1002/ $\underline{\text { fee. } 2230}$

Kuang, D., and K. H. Liao. 2020. Learning from floods: linking flood experience and flood resilience. Journal of Environmental Management 271:111025. https://doi.org/10.1016/j.jenvman.2020.111025

Kunreuther, H., S. Gupta, V. Bosetti, R. Cooke, V. Dutt, M. HaDuong, H. Held, J. Llanes-Regueiro, A. Patt, E. Shittu, and E. Weber. 2014. Integrated risk and uncertainty assessment of climate change response policies. Pages 151-206 in O. Edenhofer, R. Pichs-Madruga, Y. Sokona, E. Farahani, S. Kadner, K. Seyboth, A. Adler, I. Baum, S. Brunner, P. Eickemeier, B. Kriemann, J. Savolainen, S. Schlömer, C. von Stechow, T. Zwickel, and J. C. Minx, editors. Climate change 2014: mitigation of climate change. Working group III contribution to the fifth assessment report of the Intergovernmental Panel on Climate Change. Cambridge University Press, Cambridge, UK, and New York, New York, USA.

Lähde, E., A. Khadka, O. Tahvonen, and T. Kokkonen. 2019. Can we really have it all? Designing multifunctionality with sustainable urban drainage system elements. Sustainability 11 (7):1854. https://doi.org/10.3390/su11071854

Larson, K. L., and J. Brumand. 2014. Paradoxes in landscape management and water conservation: examining neighborhood norms and institutional forces. Cities and the Environment (CATE) 7(1):6. [online] URL: https://digitalcommons.lmu.edu/ cate/vol7/iss $1 / 6 /$

Liao, K. 2012. A theory on urban resilience to floods: a basis for alternative planning practices. Ecology and Society 17(4):48. https://doi.org/10.5751/ES-05231-170448

Lumber, R., M. Richardson, and D. Sheffield. 2017. Beyond knowing nature: contact, emotion, compassion, meaning, and beauty are pathways to nature connection. PloS ONE 12(5): e0177186. https://doi.org/10.1371/journal.pone.0177186

Lund, N. S. V., M. Borup, H. Madsen, O. Mark, K. ArnbjergNielsen, and P. S. Mikkelsen. 2019. Integrated stormwater inflow control for sewers and green structures in urban landscapes. Nature Sustainability 2:1003-1010. https://doi.org/10.1038/ s41893-019-0392-1

Markevych, I., J. Schoierer, T. Hartig, A. Chudnovsky, P. Hystad, A. M. Dzhambov, S. de Vries, M. Triguero-Mas, M. Brauer, M. 
J. Nieuwenhuijsen, G. Lupp, E. A. Richardson, T. Astell-Burt, D. Dimitrova, X. Feng, M. Sadeh, M. Standl, J. Heinrich, and E. Fuertes. 2017. Exploring pathways linking greenspace to health: theoretical and methodological guidance. Environmental Research 158:301-317. https://doi.org/10.1016/j.envres.2017.06.028

Martin, C. J., J. Evans, and A. Karvonen. 2018. Smart and sustainable? Five tensions in the visions and practices of the smart-sustainable city in Europe and North America. Technological Forecasting and Social Change 133:269-278. https://doi.org/10.1016/j.techfore.2018.01.005

McDougall, C. W., R. S. Quilliam, N. Hanley, and D. M. Oliver. 2020. Freshwater blue space and population health: an emerging research agenda. Science of the Total Environment 737:140196. https://doi.org/10.1016/j.scitotenv.2020.140196

McPhearson, T., C. M. Raymond, N. Gulsrud, C. Albert, N. Coles, N. Fagerholm, M. Nagatsu, A. S. Olafsson, N. Soininen, and K. Vierikko. 2021. Radical changes are needed for transformations to a good Anthropocene. npj Urban Sustainability 1(1):1-13. https://doi.org/10.1038/s42949-021-00017$\underline{\mathrm{x}}$

Meyer, E. K. 2008. Sustaining beauty. The performance of appearance: a manifesto in three parts. Journal of Landscape Architecture 3(1):6-23. https://doi.org/10.1080/18626033.2008.9723392

Monaghan, P., S. Hu, G. Hansen, E. Ott, C. Nealis, and M. Morera. 2016. Balancing the ecological function of residential stormwater ponds with homeowner landscaping practices. Environmental Management 58(5):843-856. https://doi.org/10.1007/ $\underline{\mathrm{s} 00267-016-0752-9}$

Mossabir, R., K. Froggatt, and C. Milligan. 2021. Therapeutic landscape experiences of everyday geographies within the wider community: a scoping review. Social Science \& Medicine 279:113980. https://doi.org/10.1016/j.socscimed.2021.113980

Mozingo, L. A. 1997. The aesthetics of ecological design: seeing science as culture. Landscape Journal 16(1):46-59. https://doi. org/10.3368/lj.16.1.46

Mullapudi, A., B. P. Wong, and B. Kerkez. 2017. Emerging investigators series: building a theory for smart stormwater systems. Environmental Science: Water Research \& Technology 3(1):66-77. https://doi.org/10.1039/C6EW00211K

Nassauer, J. I. 1992. The appearance of ecological systems as a matter of policy. Landscape Ecology 6(4):239-250. https://doi. org/10.1007/BF00129702

Nassauer, J. I. 1995a. Culture and changing landscape structure. Landscape Ecology 10(4):229-237. https://doi.org/10.1007/ $\underline{\mathrm{BF} 00129257}$

Nassauer, J. I. 1995b. Messy ecosystems, orderly frames. Landscape Journal 14(2):161-170. https://doi.org/10.3368/ 1j.14.2.161

Nassauer, J. I. 1997. Cultural sustainability: aligning aesthetics and ecology. Pages 65-83 in J. I. Nassauer, editor. Placing nature: culture and landscape ecology. Island, Washington, D.C., USA.
Nassauer, J. I. 2011. Care and stewardship: from home to planet. Landscape and Urban Planning 100(4):321-323. https://doi. org/10.1016/j.landurbplan.2011.02.022

Nassauer, J. I., N. J. Webster, N. Sampson, and J. Li. 2021. Care and safety in neighborhood preferences for vacant lot greenspace in legacy cities. Landscape and Urban Planning 214:104156. https://doi.org/10.1016/j.landurbplan.2021.104156

Nesshöver, C., T. Assmuth, K. N. Irvine, G. M. Rusch, K. A. Waylen, B. Delbaere, D. Haase, L. Jones-Walters, H. Keune, E. Kovacs, K. Krauze, M. Külvik, F. Rey, J. van Dijk, O. I. Vistad, M. E. Wilkinson, and H. Wittmer. 2017. The science, policy and practice of nature-based solutions: an interdisciplinary perspective. Science of the Total Environment 579:1215-1227. https://doi.org/10.1016/j.scitotenv.2016.11.106

Nitoslawski, S. A., N. J. Galle, C. K. Van Den Bosch, and J. W. N. Steenberg. 2019. Smarter ecosystems for smarter cities? A review of trends, technologies, and turning points for smart urban forestry. Sustainable Cities and Society 51:101770. https://doi. org/10.1016/j.scs.2019.101770

Pauleit, S., T. Zölch, R. Hansen, T. B. Randrup, and C. K. van den Bosch. 2017. Nature-based solutions and climate change: four shades of green. Pages 29-49 in In N. Kabisch, H. Korn, J. Stadler, and A. Bonn, editors. Nature-based solutions to climate change adaptation in urban areas. Springer, Cham, Switzerland. https:// doi.org/10.1007/978-3-319-56091-5 3

Raymond, C. M., P. Berry, M. Breil, M. R. Nita, N. Kabisch, M. de Bel, V. Enzi, N. Frantzeskaki, D. Geneletti, M. Cardinaletti, L. Lovinger, C. Basnou, A. Monteiro, H. Robrecht, G. Sgrigna, L. Munari, and C. Calfapietra. 2017. An impact evaluation framework to support planning and evaluation of nature-based solutions projects. Report prepared by the EKLIPSE Expert Working Group on Nature-Based Solutions to Promote Climate Resilience in Urban Areas. UK Centre for Ecology and Hydrology, Wallingford, UK. [online] URL: https://ora.ox.ac.uk/ objects/uuid:3ecfc907-1971-473a-87f3-63d1204120f0

Saito, Y. 2007. Everyday aesthetics. Oxford University Press, Oxford, UK.

Saito, Y. 2017. Aesthetics of the familiar: everyday life and worldmaking. Oxford University Press, Oxford, UK.

Samuelson, W., and R. Zeckhauser. 1988. Status quo bias in decision making. Journal of Risk and Uncertainty 1(1):7-59. https://doi.org/10.1007/BF00055564

Samuelsson, K., M. Giusti, G. D. Peterson, A. Legeby, S. A. Brandt, and S. Barthel. 2018. Impact of environment on people's everyday experiences in Stockholm. Landscape and Urban Planning 171:7-17. https://doi.org/10.1016/j.landurbplan.2017.11.009

Sánchez-Pantoja, N., R. Vidal, and M. C. Pastor. 2018. Aesthetic impact of solar energy systems. Renewable and Sustainable Energy Reviews 98:227-238. https://doi.org/10.1016/j.rser.2018.09.021

Sander, H. A., and R. G. Haight. 2012. Estimating the economic value of cultural ecosystem services in an urbanizing area using hedonic pricing. Journal of Environmental Management 113:194-205. https://doi.org/10.1016/j.jenvman.2012.08.031 
Schill, C., J. M. Anderies, T. Lindahl, C. Folke, S. Polasky, J. C. Cárdenas, A. Crépin, M. A. Janssen, J. Norberg, and M. Schlüter. 2019. A more dynamic understanding of human behaviour for the Anthropocene. Nature Sustainability 2(12):1075-1082. https://doi.org/10.1038/s41893-019-0419-7

Shishegar, S., S. Duchesne, G. Pelletier, and R. Ghorbani. 2021. A smart predictive framework for system-level stormwater management optimization. Journal of Environmental Management 278:111505. https://doi.org/10.1016/j.jenvman.2020.111505

Soga, M., and K. J. Gaston. 2016. Extinction of experience: the loss of human-nature interactions. Frontiers in Ecology and the Environment 14(2):94-101. https://doi.org/10.1002/fee.1225

Sohn, W., H. W. Kim, J. H. Kim, and M. H. Li. 2020. The capitalized amenity of green infrastructure in single-family housing values: an application of the spatial hedonic pricing method. Urban Forestry and Urban Greening 126643. https:// doi.org/10.1016/j.ufug.2020.126643

Tan, P. Y., J. Zhang, M. Masoudi, J. B. Alemu, P. J. Edwards, A. Grêt-Regamey, D. R. Richards, J. Saunders, X. P. Song, and L. W. Wong. 2020. A conceptual framework to untangle the concept of urban ecosystem services. Landscape and Urban Planning 200:103837. https://doi.org/10.1016/j.landurbplan.2020.103837

Termorshuizen, J. W., and P. Opdam. 2009. Landscape services as a bridge between landscape ecology and sustainable development. Landscape Ecology 24(8):1037-1052. https://doi. org/10.1007/s10980-008-9314-8

Tversky, A., and D. Kahneman. 1991. Loss aversion in riskless choice: a reference-dependent model. Quarterly Journal of Economics 106(4):1039-1061. https://doi.org/10.2307/2937956

Vlami, V., J. Danek, S. Zogaris, E. Gallou, I. P. Kokkoris, G. Kehayias, and P. Dimopoulos. 2020. Residents' views on landscape and ecosystem services during a wind farm proposal in an island protected area. Sustainability 12(6):2442. https://doi. org/10.3390/su12062442

Völker, S., and T. Kistemann. 2011. The impact of blue space on human health and well-being-salutogenetic health effects of inland surface waters: a review. International Journal of Hygiene and Environmental Health 214(6):449-460. https://doi. org/10.1016/j.ijheh.2011.05.001

White, M., A. Smith, K. Humphryes, S. Pahl, D. Snelling, and M. Depledge. 2010. Blue space: the importance of water for preference, affect, and restorativeness ratings of natural and built scenes. Journal of Environmental Psychology 30(4):482-493. https://doi.org/10.1016/j.jenvp.2010.04.004

Williams, J., R. Jose, C. Moobela, D. Hutchinson, R. Wise, and M. Gaterell. 2019. Residents' perceptions of sustainable drainage systems as highly functional blue green infrastructure. Landscape and Urban Planning 190:103610. https://doi.org/10.1016/j. landurbplan.2019.103610

Wilson, S. M. 2009. An ecologic framework to study and address environmental justice and community health issues. Environmental Justice 2(1):15-24. http://doi.org/10.1089/env.2008.0515
Woolf, S. H. 2017. Progress in achieving health equity requires attention to root causes. Health Affairs 36(6):984-991. https://doi. org/10.1377/hlthaff.2017.0197 